Supplement of

\title{
Heterogeneous sulfate aerosol formation mechanisms during wintertime Chinese haze events: air quality model assessment using observations of sulfate oxygen isotopes in Beijing
}

Jingyuan Shao et al.

Correspondence to: Becky Alexander (beckya@uw.edu), Lin Zhang (zhanglg@ pku.edu.cn) and Zhouqing Xie (zqxie@ustc.edu.cn)

The copyright of individual parts of the supplement might differ from the CC BY 4.0 License. 


\section{Text S1. Calculation of $\Delta^{17} \mathrm{O}\left(\mathrm{SO}_{4}{ }^{2-}\right)$ in the model}

The oxygen isotopic composition of sulfate $\left(\Delta^{17} \mathrm{O}\left(\mathrm{SO}_{4}{ }^{2-}\right)\right)$ in the model is calculated as follows:

$$
\begin{aligned}
& \Delta^{17} \mathrm{O}\left(\mathrm{SO}_{4}{ }^{2-}\right) \\
& =\frac{C_{\text {cloud }, \mathrm{H}_{2} \mathrm{O}_{2}} \times 0.7+C_{\text {cloud }, \mathrm{O}_{3}} \times 9.75+C_{\text {het }, \mathrm{H}_{2} \mathrm{O}_{2}} \times 0.7+C_{\text {het }, \mathrm{O}_{3}} \times 9.75}{C_{\text {gas }}+C_{\text {cloud }}+C_{\text {het }}+C_{\text {primary }}}
\end{aligned}
$$

where $C_{\text {gas }}, C_{\text {cloud }}, C_{\text {het }}, C_{\text {primary }}$ respectively represents sulfate concentration from gas-phase oxidation of $\mathrm{SO}_{2}$, aqueous phase oxidation of $\mathrm{S}(\mathrm{IV})$ in clouds, heterogeneous oxidation of $\mathrm{SO}_{2}$ on aerosol surfaces, and primary sulfate. The assumed $\Delta^{17} \mathrm{O}\left(\mathrm{SO}_{4}{ }^{2-}\right)$ value for each sulfate production pathway is summarized in Table $\mathrm{S} 1$.

10

In contrast to previous studies (e.g., He et al., 2017), we assume that the terminal oxygen atom is transferred to S(IV) during oxidation based on Liu et al. (2001), leading to higher $\Delta^{17} \mathrm{O}\left(\mathrm{SO}_{4}{ }^{2-}\right)$ values than those when assuming all three oxygen atoms of ozone are equally likely to be transferred to the product sulfate.

Table S1. $\Delta^{17} \mathrm{O}\left(\mathrm{SO}_{4}{ }^{2-}\right)$ value for each sulfate production pathway used in the GEOS-

\begin{tabular}{|c|c|c|}
\hline \multicolumn{2}{|c|}{ Sulfate formation pathway } & \multirow{2}{*}{$\begin{array}{l}\Delta^{17} \mathrm{O}\left(\mathrm{SO}_{4}^{2-}\right) \% 0 \\
0\end{array}$} \\
\hline Gas & $\mathrm{SO}_{2}+\mathrm{OH}$ & \\
\hline \multirow{3}{*}{ In Cloud } & $\mathrm{S}(\mathrm{IV})+\mathrm{H}_{2} \mathrm{O}_{2}$ & 0.7 \\
\hline & $\mathrm{S}(\mathrm{IV})+\mathrm{O}_{3}$ & $9.75^{\mathrm{a}}$ \\
\hline & $\mathrm{S}(\mathrm{IV})+\mathrm{TMI}$ & 0 \\
\hline \multirow{4}{*}{$\begin{array}{l}\text { On aerosol surface } \\
\text { (Heterogeneous) }\end{array}$} & $\mathrm{S}(\mathrm{IV})+\mathrm{H}_{2} \mathrm{O}_{2}$ & 0.7 \\
\hline & $\mathrm{S}(\mathrm{IV})+\mathrm{O}_{3}$ & 9.75 \\
\hline & $\mathrm{S}(\mathrm{IV})+\mathrm{TMI}$ & 0 \\
\hline & $\mathrm{S}(\mathrm{IV})+\mathrm{NO}_{2}$ & 0 \\
\hline Primary sulfate & & 0 \\
\hline
\end{tabular}
Chem model ${ }^{1}$ 
Text S2. Influence of aerosol pH on reaction probability and sulfate production rate

Figure S1 shows the calculated reaction probability $(\gamma$, Section 2$)$ and sulfate production rate $(R)$ as a function of aerosol $\mathrm{pH}$ for the four heterogeneous sulfate production mechanisms implemented into the model (TMI, $\mathrm{O}_{3}, \mathrm{H}_{2} \mathrm{O}_{2}$ and $\mathrm{NO}_{2}$ ) plus two additional pathways, heterogeneous $\mathrm{S}(\mathrm{IV})$ oxidation by $\mathrm{HOBr}$ and $\mathrm{O}_{2}$ on acidic microdroplets as proposed by Hung and Hoffmann (2015). Concentrations used in the calculations shown in Figure S1 represent the HPP conditions: $\left[\mathrm{SO}_{2}(\mathrm{~g})\right]=20 \mathrm{ppb}$, $\left[\mathrm{NO}_{2}(\mathrm{~g})\right]=85 \mathrm{ppb},\left[\mathrm{O}_{3}(\mathrm{~g})\right]=11 \mathrm{ppb},\left[\mathrm{H}_{2} \mathrm{O}_{2}(\mathrm{~g})\right]=0.3 \mathrm{ppb},[\mathrm{HOBr}(\mathrm{g})]=0.1 \mathrm{ppt}$, total soluble Fe and $\mathrm{Mn}$ are estimated to 10 and $20 \mathrm{ng} \mathrm{m}^{-3}$. Concentrations of $\mathrm{H}_{2} \mathrm{O}_{2}$ is from Ye et al., (2018) and HOBr is from the standard model simulation, and all others are from observations. The mass accommodation coefficients ( $\alpha$ in Eq. (3) in the main text) for $\mathrm{SO}_{2}, \mathrm{NO}_{2}, \mathrm{O}_{3}, \mathrm{H}_{2} \mathrm{O}_{2}$, and $\mathrm{HOBr}$ are $0.23,2 \times 10^{-4}$ (Jacob, 2000), $2 \times 10^{-3}$ (Jacob, 2000),

35 0.11, and 0.6 (Chen et al., 2016), respectively. Aerosol radius ( $a$ in Eq. (1)) and total aerosol surface area ( $A$ in Eq. (1)) depend on the type of aerosol. Here we use $a=1.5 \times 10^{-}$ ${ }^{5} \mathrm{~cm}$ (Cheng, et al., 2016) and $\mathrm{A}=12 \times 10^{-5} \mathrm{~cm}^{2} \mathrm{~cm}^{-3}$.

As shown in Figure $\mathrm{S} 1$, the calculated reaction probabilities $(\gamma)$ and sulfate production rates $(R)$ are strongly $\mathrm{pH}$ dependent for the different sulfate formation pathways, with the exception of the $\mathrm{H}_{2} \mathrm{O}_{2}$ pathway. The calculated $\gamma$ for $\mathrm{H}_{2} \mathrm{O}_{2}$ oxidation is on the order of $10^{-4}$ for all aerosol $\mathrm{pH}$ values. The lack of $\mathrm{pH}$ dependence for $\mathrm{S}(\mathrm{IV})$ oxidation by $\mathrm{H}_{2} \mathrm{O}_{2}$ is due to the competing effects of increases in the pseudo-first order reaction rate constant with $\left[\mathrm{H}^{+}\right]$(the reaction is acid catalyzed) and decreasing $\mathrm{SO}_{2}$ solubility with decreasing $\mathrm{pH}$. The reaction probabilities and sulfate production rates for $\mathrm{O}_{3}$ and $\mathrm{NO}_{2}$ pathways increase with increasing $\mathrm{pH}$ because of the increase in the effective Henry's law constant of $\mathrm{SO}_{2}$ with $\mathrm{pH}$, and are limited by mass transport across the air water interface at high $\mathrm{pH}$ values $(\mathrm{pH}>7)$. TMI-catalyzed oxidation plays an important role when $\mathrm{pH}<4$ due to the increased solubility of $\mathrm{Fe}$ and $\mathrm{Mn}$ at low $\mathrm{pH}$. Heterogeneous sulfate production rates calculated as first order in $\mathrm{SO}_{2}$ or oxidant concentrations result in similar values when aerosol $\mathrm{pH}<6$, and are limited by the mass transport across the 
air-water interface at higher $\mathrm{pH}$ values. Calculated $\gamma$ ranges from $8 \times 10^{-6}-7 \times 10^{-4}$ over all aerosol $\mathrm{pH}$ values, consistent with the $\gamma$ values used in previous studies (Cheng et al., 2016; Zheng et al., 2015). Figure $\mathrm{S} 1$ also shows calculated $\Delta^{17} \mathrm{O}\left(\mathrm{SO}_{4}{ }^{2-}\right)$ for sulfate 55 produced via heterogeneous production pathways. Calculated heterogeneous $\Delta^{17} \mathrm{O}\left(\mathrm{SO}_{4}{ }^{2-}\right)$ is lower than $0.1 \%$ when $\mathrm{pH}<4$, is about $0.6 \%$ when $\mathrm{pH}$ is between 3 and 5 , and increases rapidly to $4.5 \%$ for $\mathrm{pH}$ of 5-7.

The reaction probability $\gamma$ for the $\mathrm{HOBr}$ pathway is limited by mass transfer when $\mathrm{pH}>$ 5 due to the large aqueous-phase rate-coefficient for this reaction. Although the $\gamma$ values for heterogeneous oxidation by $\mathrm{HOBr}$ are high (on the order of $10^{-1}$ as shown in Figure S1), the sulfate production rate is relatively low due to low $\mathrm{HOBr}$ concentrations (0.1 ppt) in the model. Chen et al. (2017) showed that HOBr concentrations were likely underestimated in GEOS-Chem; however, $\mathrm{HOBr}$ observations in China are not available for comparison with model results shown here. Due to the estimated low reaction rate for heterogeneous sulfate production via oxidation by $\mathrm{HOBr}$ and the lack of relevant observational constraints, we do not further consider this reaction pathway in this study. We note that this should be revisited in the future when observational constraints on $\mathrm{HOBr}$ abundance become available.

The heterogeneous sulfate production rate for $\mathrm{SO}_{2}$ oxidation by $\mathrm{O}_{2}$ on acidic microdroplets is very large due to calculated high $\gamma$ values (resulting from the large aqueous-phase rate constant in Hung and Hoffman (2015)) and $\mathrm{SO}_{2}$ concentrations (Figure S1). Implementation of this heterogeneous sulfate formation pathway into

75 GEOS-Chem results in 95\% of total, global, tropospheric sulfate formation occurring via this pathway (figure not shown), even though it only occurs in the model when calculated aerosol $\mathrm{pH}$ is lower than 3 . This result seems highly unrealistic, and thus we do not consider it further here. 


\section{Text S3 Comparison of Observed and Modeled Seasonal Mean Mn and Fe}

The parameterization of TMI-catalyzed S(IV) oxidation in clouds in GEOS-Chem is described in Alexander et al., (2009). The natural source of Fe ([Fe $\left.]_{\text {nat }}\right)$ and $\mathrm{Mn}\left([\mathrm{Mn}]_{\text {nat }}\right)$

85 from mineral dust are scaled to total dust mass. [Fe $]_{\text {nat }}$ is 3.5\% of total dust mass and $[\mathrm{Mn}]_{\mathrm{nat}}$ is a factor of 50 lower than $[\mathrm{Fe}]_{\text {nat }}$ (Alexander et al., 2009). The anthropogenic source of $\mathrm{Fe}\left([\mathrm{Fe}]_{\mathrm{ant}}\right)$ and $\mathrm{Mn}\left([\mathrm{Mn}]_{\mathrm{ant}}\right)$ from coal combustion are scaled to the abundance of primary anthropogenic sulfate due to their common source and atmospheric lifetime $[\mathrm{Mn}]_{\text {ant }}$ is $1 / 300$ of primary sulfate concentration and $[\mathrm{Fe}]_{\text {ant }}$ is 10

90 times that of $[\mathrm{Mn}]_{\mathrm{ant}}$ as described in Alexander et al. (2009). Figure S4 show the distribution of simulated $[\mathrm{Fe}]_{\text {nat }}$ and $[\mathrm{Fe}]_{\text {ant }}$ during the entire model simulation period. Table S2 compares autumn-winter mean modeled Mn and Fe with the observations at several sites in east Asia, including 3 sites in the North China Plain(NCP) region (Beijing, Tianjin and Shijiazhuang), 2 sites in the Sichuan Basin (Chengdu and Chongqing), and Lanzhou and Seoul which are the upwind and downwind of Beijing, respectively. The model tends to underestimate both Fe and Mn at the NCP sites by a factor of 0.25-0.72. Model comparison with observations in the Sichuan Basin shows good agreement on Mn concentration (within 20\% for both Chongqing and Chengdu), with model calculations overestimating the observations of $\mathrm{Fe}$ concentrations. For sites in Lanzhou (northwest of Beijing, upwind) and Seoul (southeast of Beijing, downwind), model comparison with observations indicates good agreement on $\mathrm{Fe}$ (within 5\%), and underestimates Mn by $60 \%$. The model underestimates Fe and Mn in the NCP region and overestimates in Sichuan Basin. These discrepancies highlight the limitations of our approach applying a global-scale factor of $[\mathrm{SO} 4]_{\text {primary }} /[\mathrm{Mn}]_{\text {ant }}$ and $[\mathrm{dust}] /[\mathrm{Fe}]_{\text {nat }}$, as

105 regionally varying emissions control technologies and mass fraction of $\mathrm{Fe}$ in dust may impact the relative emission rates.

However, sulfate formation by the TMI-catalyzed oxidation pathway is influenced by soluble $\mathrm{Fe}^{3+}$ and $\mathrm{Mn}^{2+}$ concentrations, as opposed to total $\mathrm{Fe}$ and $\mathrm{Mn}$. Previous studies 110 suggest that the solubility of $\mathrm{Fe}$ and $\mathrm{Mn}$ ranges from 0.03 to $54 \%$ and 1.2 to $97 \%$, respectively. The solubility of metals is influenced by several factors such as the natural 
versus anthropogenic origin of samples (A.R. Baker et al., 2006; K.V. Desboeufs et al., 2005; K.V. Desboeufs et al., 2001; Spokes et al., 1994; A. Ito1 and Y. Feng, 2010; P.Y. Chuang et al., 2005; Solmon et al., 2009), acidity, and sunlight. In this study, we 115 assume a solubility of $10 \%$ for $[\mathrm{Fe}]_{\text {ant }}, 0.45 \%$ for $[\mathrm{Fe}]_{\mathrm{nat}}, 50 \%$ for $[\mathrm{Mn}]_{\text {ant }}$, and $5 \%$ for $[\mathrm{Mn}]_{\text {nat }}$ in cloud water. The modeled soluble $\mathrm{Fe}^{3+}$ and $\mathrm{Mn}^{2+}$ concentration is shown in Table S3. After modification, the average modeled concentration of soluble Fe(III) in cloud water during our study period is $2.9 \pm 1.8 \mu \mathrm{M}$ and $\mathrm{Mn}(\mathrm{II})$ is $1.3 \pm 0.7 \mu \mathrm{M}$, which is consistent with estimates (He et al., 2018) and observations (Shen et al., 2012; Guo 120 et al., 2012). A sensitivity study is performed based on Run_TMI but with the higher solubility of Fe and $\mathrm{Mn}$ as Alexander et al. (2009): the solubility of $1 \%$ of [Fe] $]_{\mathrm{nat}}$ and $50 \%$ for $[\mathrm{Mn}]_{\text {nat }}$ in cloud water. The modeled soluble Fe(III) and $\mathrm{Mn}(\mathrm{II})$ concentration reaches $20 \mu \mathrm{M}$ and $10 \mu \mathrm{M}$ during HPP, up to a factor of 5 higher than the observations. The simulated sulfate concentration is also overestimated the observation by around $125 \quad 100 \%$ during HPP in Beijing.

Table S2. Comparison of observed and modeled autumn and winter mean $\mathrm{Mn}$ and Fe concentrations $\left(\mathrm{ng} \mathrm{m}^{-3}\right)$ from several East Asian locations.

\begin{tabular}{lcccc}
\hline Location & $\begin{array}{c}\text { Fe }(\mathrm{Mn}) \\
\text { observation } \\
\left(\mathrm{ng} \mathrm{m}^{-3}\right)\end{array}$ & $\begin{array}{c}\mathrm{Fe}(\mathrm{Mn}) \\
\text { model } \\
\left(\mathrm{ng} \mathrm{m}^{-3}\right)\end{array}$ & $\begin{array}{c}\text { Fe }(\mathrm{Mn}) \\
\text { Model/observation }\end{array}$ & Reference \\
\hline Beijing & $1800(90)$ & $835(22.7)$ & $0.46(0.25)$ & Zhao et al. (2013) \\
Tianjin & $1980(120)$ & $1239(36.2)$ & $0.72(0.30)$ & \\
Shijiazhuang & $2250(150)$ & $1615(44.3)$ & $0.63(0.30)$ & Wang et al. (2018) \\
Chengdu & $875(38)$ & $1245.7(34.1)$ & $1.42(0.90)$ & Wang et al. (2016) \\
Chongqing & $502.5(36.5)$ & $1226.0(39.7)$ & $2.4(1.09)$ & Park et al. (2018) \\
Lanzhou & $1534(59)$ & $1456.9(33.0)$ & $0.95(0.56)$ & \\
Seoul & $227(21)$ & $219.8(6.1)$ & $0.97(0.30)$ & \\
\hline
\end{tabular}

130 Table S3. Comparison of observed and modeled soluble $\mathrm{Mn}$ (II) and $\mathrm{Fe}(\mathrm{III})$ concentrations $(\mu \mathrm{M})$.

\begin{tabular}{ccccc}
\hline & $\begin{array}{c}\text { This study } \\
\text { Range } \\
\text { (monthly mean) }\end{array}$ & $\begin{array}{c}\text { Beijing } \\
\text { (He et al., 2018) }\end{array}$ & $\begin{array}{c}\text { Mt. Tai } \\
\text { (Shen et al., 2012) }\end{array}$ & $\begin{array}{c}\text { Mt. Tai } \\
\text { (Guo et al., 2012) }\end{array}$ \\
\hline $\mathrm{Fe}(\mathrm{III})$ & $\begin{array}{c}0.4-11.2 \\
(2.9 \pm 2.7)\end{array}$ & $\begin{array}{c}0.6-6.1 \\
(2.6 \pm 1.8)\end{array}$ & $0.8-7.4$ & 2.6 \\
\hline $\mathrm{Mn}(\mathrm{II})$ & $\begin{array}{c}0.4-4.8 \\
(1.3 \pm 0.9)\end{array}$ & 1 & $0.4-1.7$ & 1.2 \\
\hline
\end{tabular}

${ }^{\mathrm{a}} \mathrm{Mt}$. Tai is located in central Shandong province at the eastern edge of the NCP region. 

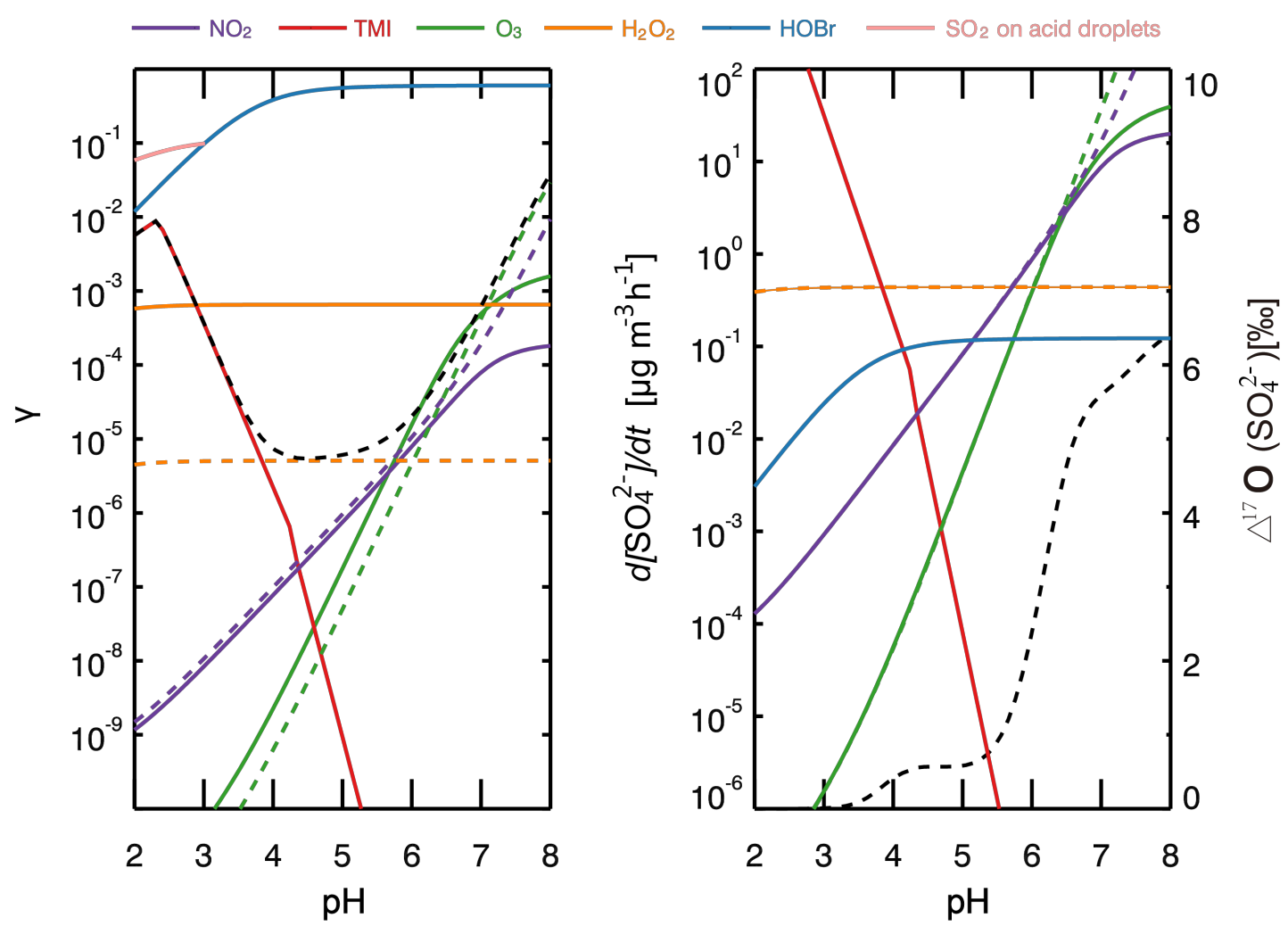

135 Figure S1. The dependence of reaction probability $\gamma$ (left) and sulfate production rates $\left(\mu \mathrm{g} \mathrm{m}^{-3} \mathrm{~h}^{-1}\right)$ (right) on aerosol $\mathrm{pH}$ for different heterogeneous sulfate formation pathways, including $\mathrm{NO}_{2}$ (purple), TMI (red), $\mathrm{O}_{3}$ (green), $\mathrm{H}_{2} \mathrm{O}_{2}$ (orange), $\mathrm{HOBr}$ (blue), and $\mathrm{SO}_{2}$ on acid droplets (pink). The sulfate production rate on acid droplets is not shown on the figure on the right because it is off scale. The solid lines are calculated as

140 first order in the oxidant, and the dashed lines are calculated as first order in $\mathrm{SO}_{2}$. The black dashed line on the left represents the sum of TMI, $\mathrm{O}_{3}, \mathrm{H}_{2} \mathrm{O}_{2}$ and $\mathrm{NO}_{2}$. The black dashed line on the right represents the calculated $\Delta^{17} \mathrm{O}\left(\mathrm{SO}_{4}{ }^{2-}\right)$ value for the four reactions of TMI, $\mathrm{O}_{3}, \mathrm{H}_{2} \mathrm{O}_{2}$ and $\mathrm{NO}_{2}$. 


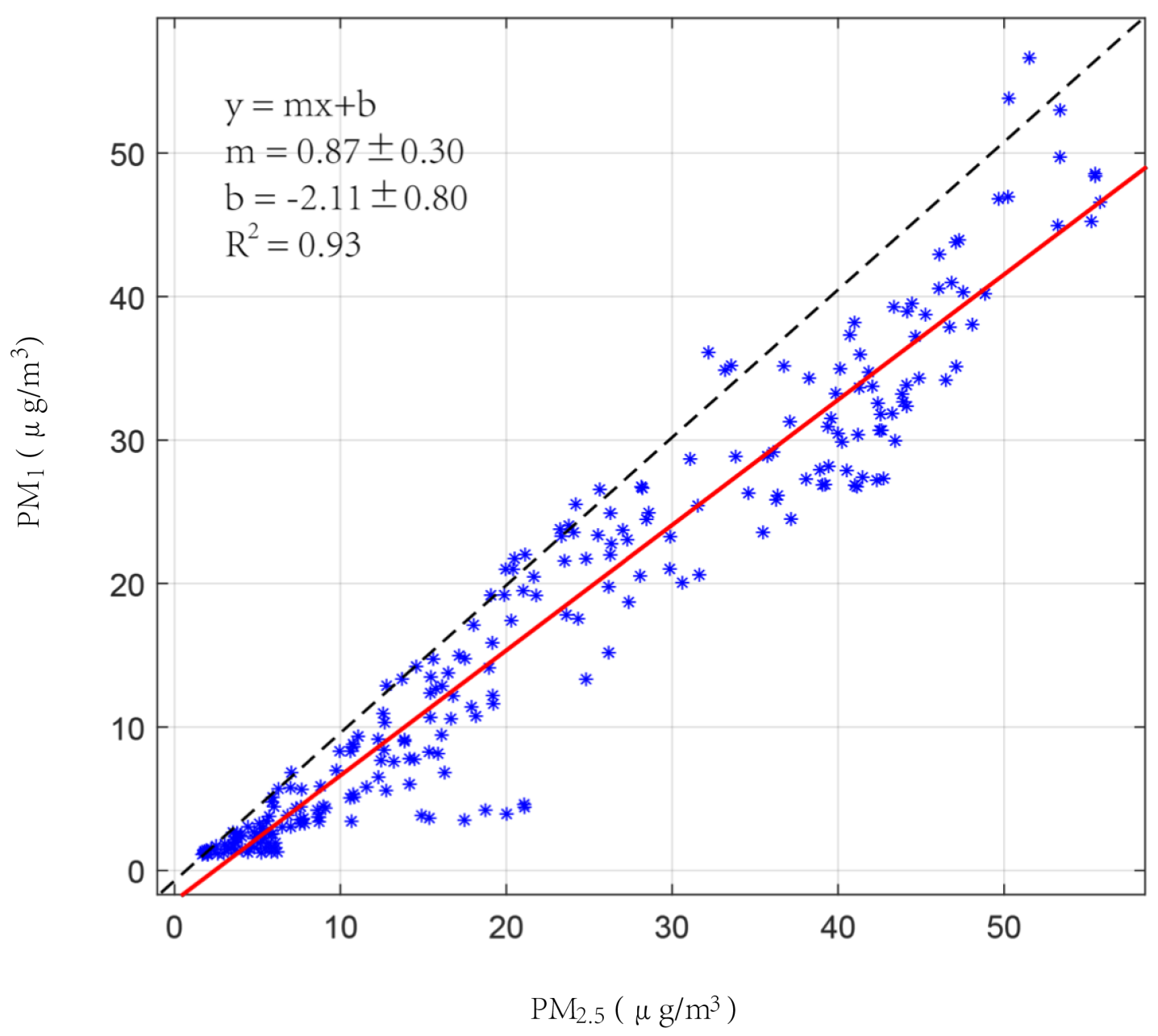

Figure S2. The relationship between sulfate concentrations in $\mathrm{PM}_{2.5}$ and $\mathrm{PM}_{1}$ measured in Beijing. 

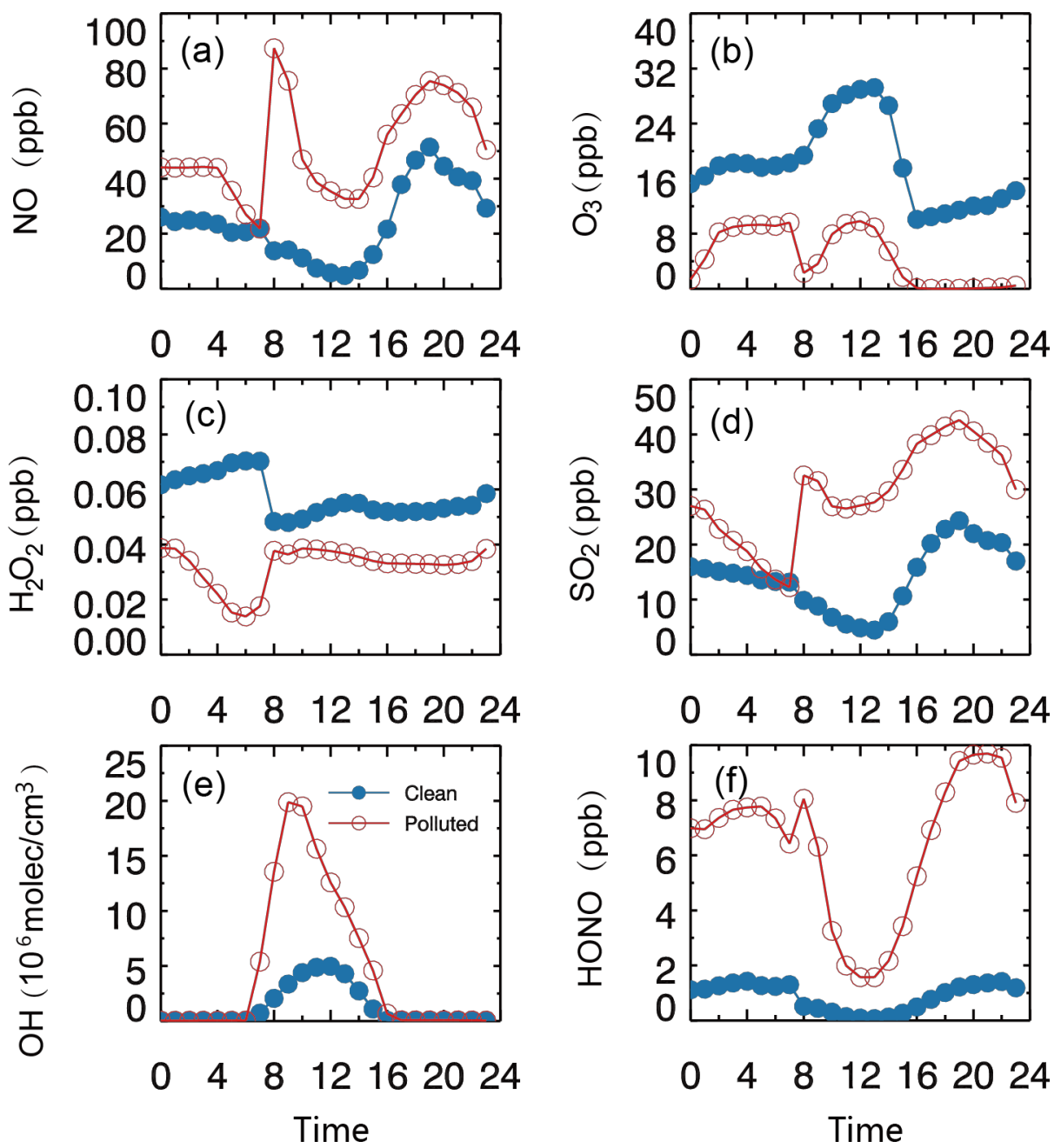

Figure S3. Modeled diurnal cycles of surface $\mathrm{NO}, \mathrm{O}_{3}, \mathrm{H}_{2} \mathrm{O}_{2}, \mathrm{SO}_{2}, \mathrm{HONO}$, and $\mathrm{OH}$ abundances in Beijing. The red lines denote averages for heavy polluted periods and the blue lines denote averages for clean periods as defined in the text. 


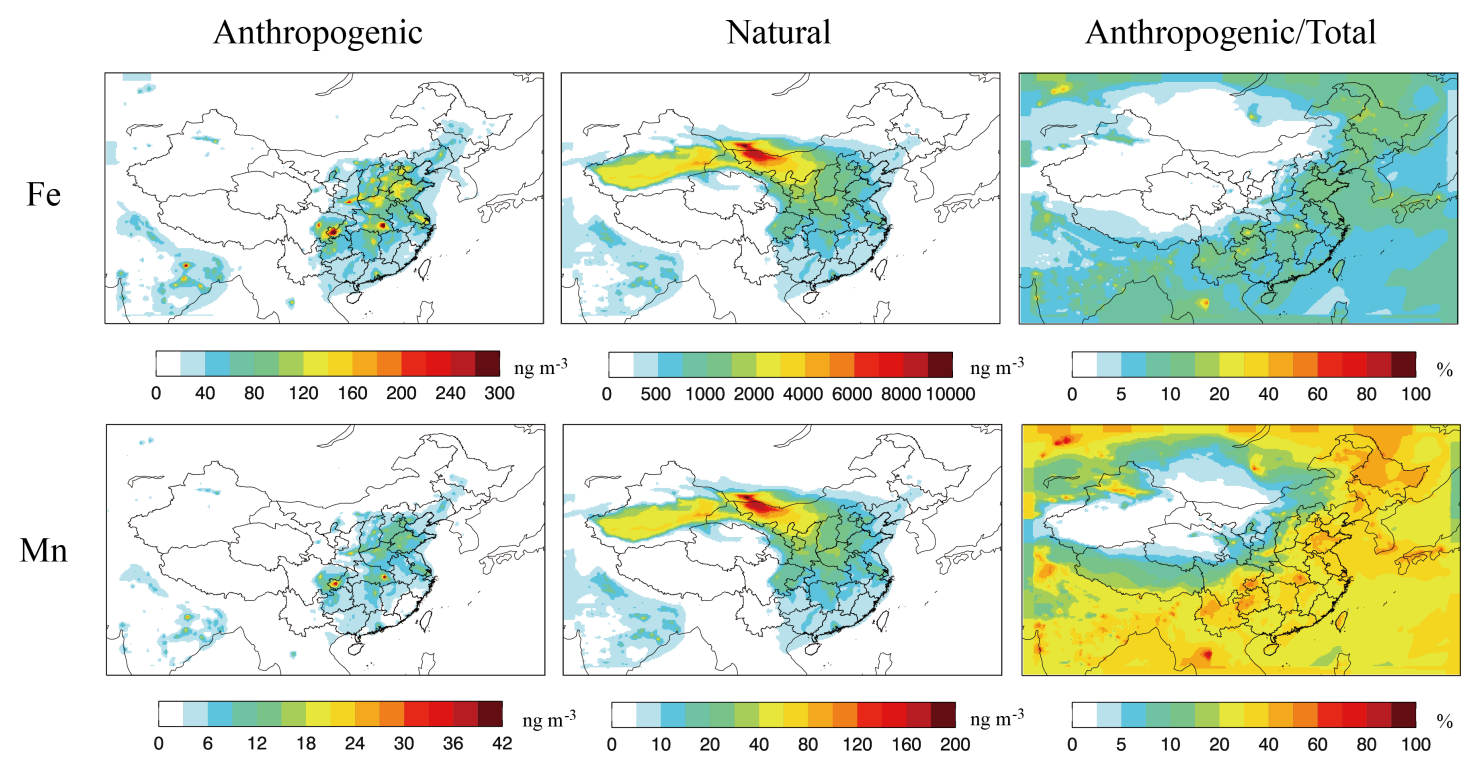

Figure S4. Modeled Anthropogenic and Natural Fe and $\mathrm{Mn}\left(\mathrm{ng} \mathrm{m}^{-3}\right)$ at the surface, 160 along with the anthropogenic/total Fe and Mn concentration percentages. 

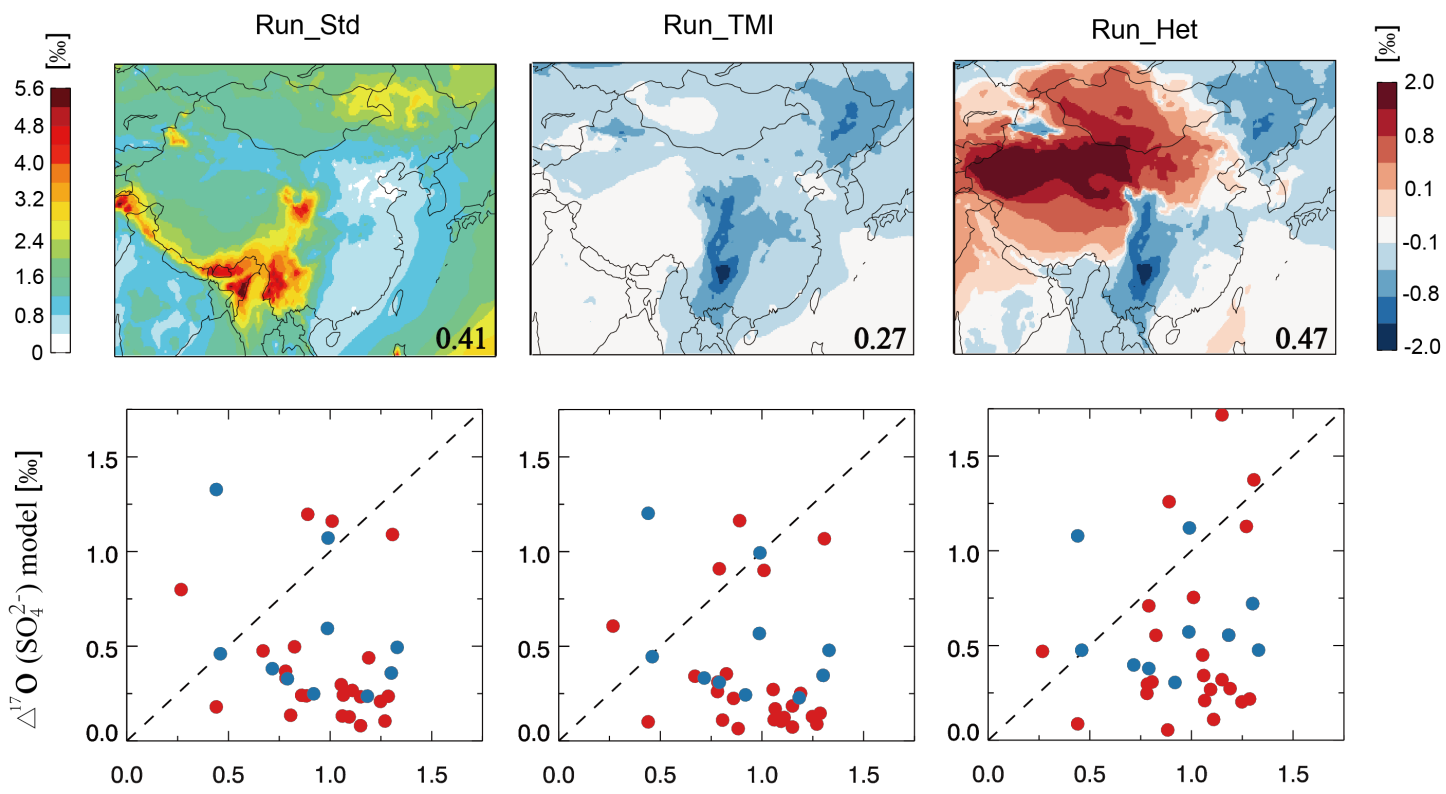

$\triangle^{17} \mathrm{O}\left(\mathrm{SO}_{4}^{2-}\right)$ observation [\%]

Figure S5. Modeled $\Delta^{17} \mathrm{O}\left(\mathrm{SO}_{4}{ }^{2-}\right)$ and comparisons with observations in Beijing. The top panels show modeled spatial distribution of $\Delta^{17} \mathrm{O}\left(\mathrm{SO}_{4}{ }^{2-}\right)$ over Asia averaged over the measurement period. The top left panel shows simulated $\Delta^{17} \mathrm{O}\left(\mathrm{SO}_{4}{ }^{2-}\right)$ in Run_Std; the middle and right panels show differences relative to Run_Std in Run_TMI and

175 Run_Het, respectively. Numbers in inset are simulated mean $\Delta^{17} \mathrm{O}\left(\mathrm{SO}_{4}{ }^{2-}\right)$ values (\%o) in Beijing averaged over the entire collection period. The bottom panels show observed vs. modeled $\Delta^{17} \mathrm{O}\left(\mathrm{SO}_{4}{ }^{2-}\right)$ in Beijing in Run_Std (left), Run_TMI (middle), and Run_Het (right) separated for heavy pollution (HPP; red circles) and clean (CP; blue circles) periods.

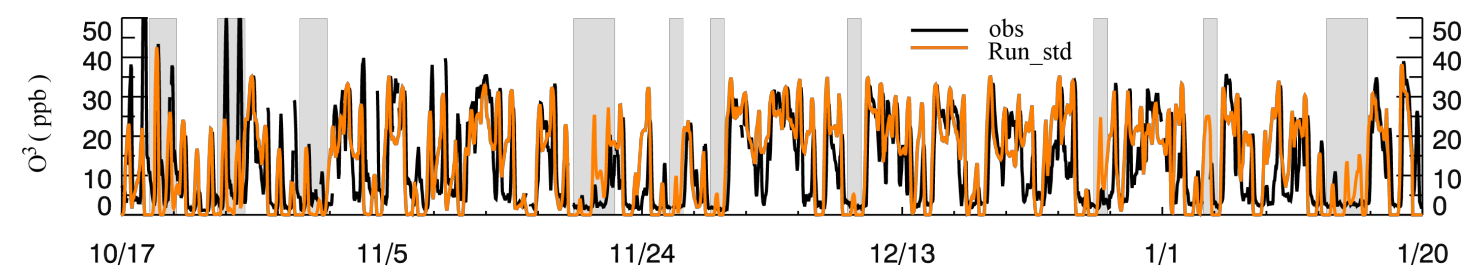

Figure S6. Time series of $\mathrm{O}_{3}$ at the surface in Beijing during the study period of 17 October 2014 - 20 January 2015. Hourly $\mathrm{O}_{3}$ observations (black line) are compared 185 with model results from Run_Std (orange line). The gray shaded bars represent 10 heavy pollution periods (HPP) as defined in the text. 


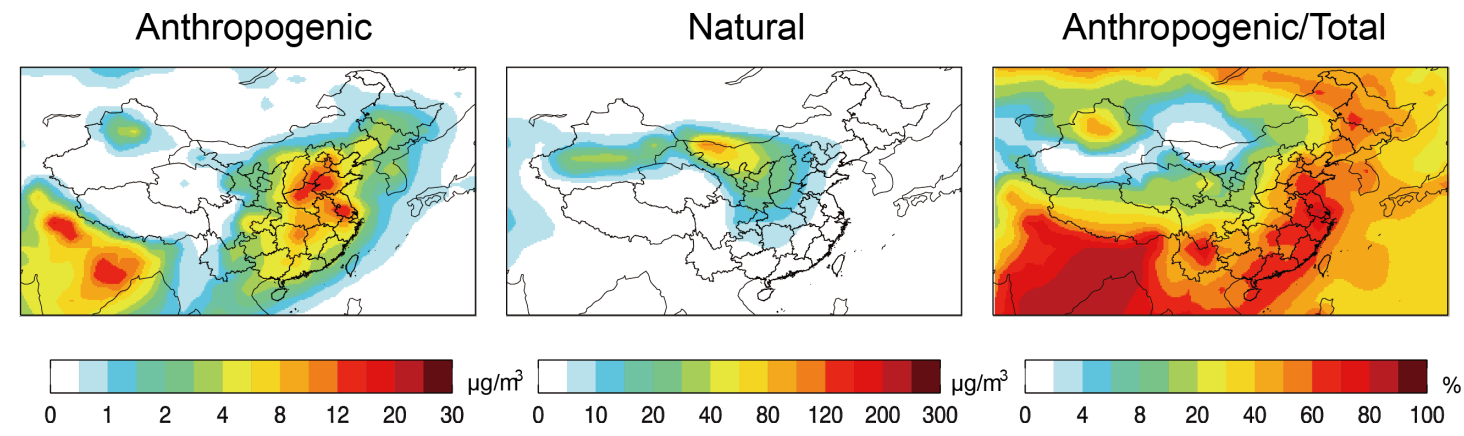

190 Figure S7. Modeled anthropogenic and natural dust $\left(\mu \mathrm{g} \mathrm{m}^{-3}\right)$ at the surface, along with the percentage contribution of anthropogenic dust to total dust concentration. 


\section{References}

Baker, A. R., Jickells, T. D., Witt, M., and Linge, K. L.: Trends in the solubility of iron, aluminium, manganese and phosphorus in aerosol collected over the Atlantic Ocean, Marine Chemistry, 98, 43-58, doi:10.1016/j.marchem.2005.06.004, 2006.

200 Chuang, P. Y., Duvall, R. M., Shafer, M. M., and Schauer, J. J.: The origin of water soluble particulate iron in the Asian atmospheric outflow, Geophys. Res. Lett., 32,07813-07817, doi:10.1029/2004g1021946, 2005.

Desboeufs, K. V., Losno, R., and Colin, J. L.: Factors influencing aerosol solubility during cloud processes, Atmos. Environ., 35, 3529-3537, doi: 10.1016/s1352-2310(00)00472-6, 2001.

205 Desboeufs, K. V., Sofikitis, A., Losno, R., Colin, J. L., and Ausset, P.: Dissolution and solubility of trace metals from natural and anthropogenic aerosol particulate matter, Chemosphere, 58, 195203, doi:10.1016/j.chemosphere.2004.02.025, 2005.

Guo, J., Wang, Y., Shen, X., Wang, Z., Lee, T., Wang, X., Li, P., Sun, M., Collett, J. L., Wang, W., and Wang, T.: Characterization of cloud water chemistry at Mount Tai, China: Seasonal variation, anthropogenic impact, and cloud processing, Atmos. Environ., 60, 467-476, doi:10.1016/j.atmosenv.2012.07.016, 2012.

He, P., Alexander, B., Geng, L., Chi, X., Fan, S., Zhan, H., Kang, H., Zheng, G., Cheng, Y., Su, H., Liu, C., and Xie, Z.: Isotopic constraints on heterogeneous sulfate production in Beijing haze, Atmos. Chem. Phys., 18, 5515-5528, doi:10.5194/acp-18-5515-2018, 2018.

215 Ito, A., and Feng, Y.: Role of dust alkalinity in acid mobilization of iron, Atmos. Chem. Phys., 10, 9237-9250, doi:10.5194/acp-10-9237-2010, 2010.

Liu, Q., L. M. Schuerter, C. E. Muller, S. Aloisio, J. S. Francisco, and D. W. Margerum (2001),

Kinetics and mechanisms of aqueous ozone reactions with bromine, sulfite, hydrogen sulfite, iodide, and nitrite ions, Inorg. Chem., 40, 4436-4442.

220 Shen, X. H., Lee, T. Y., Guo, J., Wang, X. F., Li, P. H., Xu, P. J., Wang, Y., Ren, Y., Wang, W., Wang, T., Li, Y., Cam, S. A., and Collett, J. L.: Aqueous phase sulfate production in clouds in eastern China, Atmos. Environ., 62, 502-511, doi:10.1016/j.atmosenv.2012.07.079, 2012.

Vicars, W. and J. Savarino . "Quantitative constraints on the ${ }^{17} \mathrm{O}$-excess ( ${ }^{17} \mathrm{O}$ ) signature of surface ozone: Ambient measurements from $50^{\circ} \mathrm{N}$ to $50^{\circ} \mathrm{S}$ using the nitrite-coated filter technique."

225 Geochem. Cosmochem. Acta 135: 270-287, 2014.

Park, S.-M., Song, I.-H., Park, J. S., Oh, J., Moon, K. J., Shin, H. J., Ahn, J. Y., Lee, M.-D., Kim, J., and Lee, G.: Variation of $\mathrm{PM}_{2.5}$ Chemical Compositions and their Contributions to Light Extinction in Seoul, Aerosol and Air Quality Research, 18, 2220-2229, doi:10.4209/aaqr.2017.10.0369, 2018.

230 Savarino, J. and M. H. Thiemens. "Analytical procedure to determine both ${ }^{18} \mathrm{O}$ and $\quad{ }^{17} \mathrm{O}_{0} \mathrm{H}_{2} \mathrm{O}_{2}$ in natural water and first measurements." Atmos. Env. 33: 3683-3690, 1996.

Sholkovitz, E. R., Sedwick, P. N., Church, T. M., Baker, A. R., and Powell, C. F.: Fractional solubility of aerosol iron: Synthesis of a global-scale data set, Geochimica et Cosmochimica Acta, 89, 173-189, 10.1016/j.gca.2012.04.022, 2012.

235 Solmon, F., Chuang, P. Y., Meskhidze, N., and Chen, Y.: Acidic processing of mineral dust iron by anthropogenic compounds over the north Pacific Ocean, J. Geophys.1 Res., 114, doi:10.1029/2008jd010417, 2009. 
Spokes, L. J., Jickells, T. D., and Lim, B.: Solubilisation of aerosol trace metals by cloud processing: A laboratory study, Geochimica et Cosmochimica Acta, 58, 3281-3287, doi:10.1016/00167037(94)90056-6, 1994.

Sun, Y. L., Wang, Z. F., Du, W., Zhang, Q., Wang, Q. Q., Fu, P. Q., Pan, X. L., Li, J., Jayne, J., and Worsnop, D. R.: Long-term real-time measurements of aerosol particle composition in Beijing, China: seasonal variations, meteorological effects, and source analysis, Atmos. Chem. Phys., 15, 10149-10165, doi:10.5194/acp-15-10149-2015, 2015.

245 Wang, H., Qiao, B., Zhang, L., Yang, F., and Jiang, X.: Characteristics and sources of trace elements in PM2.5 in two megacities in Sichuan Basin of southwest China, Environ. Pollut., 242, 15771586, doi:10.1016/j.envpol.2018.07.125, 2018.

Wang, Y., Jia, C., Tao, J., Zhang, L., Liang, X., Ma, J., Gao, H., Huang, T., and Zhang, K.: Chemical characterization and source apportionment of $\mathrm{PM}_{2.5}$ in a semi-arid and petrochemicalindustrialized city, Northwest China, Sci. Total Environ., 573, 1031-1040, doi:10.1016/j.scitotenv.2016.08.179, 2016.

Ye, C., Liu, P., Ma, Z., Xue, C., Zhang, C., Zhang, Y., Liu, J., Liu, C., Sun, X., and Mu, Y.: High $\mathrm{H}_{2} \mathrm{O}_{2}$ Concentrations Observed during Haze Periods during the Winter in Beijing: Importance of $\mathrm{H}_{2} \mathrm{O}_{2}$ Oxidation in Sulfate Formation, Environ. Sci. Technol. Lett., 5, 757-763,

255 doi:10.1021/acs.estlett.8b00579, 2018.

Zhang, Y., Wen, L., Chen, J., Wang, X., Xue, L., Yang, L., Wang, L., Li, Z., Yu, C., Chen, T., and Wang, W.: Trend in Fine Sulfate Concentrations and the Associated Secondary Formation Processes at an Urban Site in North China, Aerosol and Air Quality Research, 18, 1519-1530, doi:10.4209/aaqr.2017.10.0358, 2018.

260 Zhao, P. S., Dong, F., He, D., Zhao, X. J., Zhang, X. L., Zhang, W. Z., Yao, Q., and Liu, H. Y.: Characteristics of concentrations and chemical compositions for $\mathrm{PM}_{2.5}$ in the region of Beijing, Tianjin, and Hebei, China, Atmos. Chem. Phys., 13, 4631-4644, doi:10.5194/acp-13-4631-2013, 2013. 